\title{
Exposure to pesticides and development of hematological cancers: a case-control
}

\section{study}

\author{
Exposição a agrotóxicos e desenvolvimento de cânceres hematológicos: um estudlo caso-controle \\ Exposición a plaguicidas y desarrollo de cánceres hematológicos: un estudio de casos y controles
}

\section{Abstract}

The aim of this study was to analyze the association between chronic exposure to pesticides and the development of hematological cancers in a region with intense agricultural activity. This is a hospital-based case-control study. Socioeconomic, demographic, occupational and health-related aspects of patients were investigated. The univariate odds ratio (OR) of cases was verified using logistic regression analysis. In the multivariate analysis, the relevant variables in the model were maintained $(\mathrm{p}=0.05)$. There was a predominance of males in the case $(54.0 \%)$ and control $(53.0 \%)$ groups. The mean age was $58.8 \pm 14.5$ years in the case group and $55.6 \pm 12.9$ years in the control group. It was found that $38.7 \%$ of the cases were farmers, and that contact for more than five years with pesticides increases the chances of developing hematological cancers by 2.19 times (OR $=2.19 ; 95 \%$ CI $1,19-4.06)$. It was also found that the higher the family income, the lower the chances of these neoplasms to appear $(\mathrm{OR}=0.26 ; 95 \% \mathrm{CI}$ $0.11-0.65)$. In addition, patients who did not have a family history of cancer were $96 \%$ less likely $(\mathrm{OR}=0.04 ; 95 \%$ CI $0.02-0.08)$ to develop the disease. Chronic exposure to pesticides, family history of cancer and socioeconomic status are associated with greater chances of developing hematological neoplasms. Rural workers exposed to these substances for periods of more than five years are more vulnerable.

Keywords: Hematological neoplasms; Occupational exposure; Pesticides; Toxicology.

\section{Resumo}

Objetivou-se neste estudo analisar a associação entre a exposição crônica a agrotóxicos e o desenvolvimento de cânceres hematológicos em uma região de intensa atividade agrícola. Este é um estudo caso-controle de base hospitalar. Aspectos socioeconômicos, demográficos, ocupacionais e relacionados à saúde dos pacientes foram investigados. A razão de chances (OR) univariada dos casos foi verificada por meio de análise de regressão logística. $\mathrm{Na}$ análise multivariada, as variáveis relevantes no modelo foram mantidas $(\mathrm{p}=0,05)$. Houve predomínio do sexo masculino nos grupos caso $(54,0 \%)$ e controle $(53,0 \%)$. A média de idade foi de $58,8 \pm 14,5$ anos no grupo caso e $55,6 \pm 12,9$ anos no grupo controle. Verificou-se que 38,7\% dos casos eram agricultores, e que o contato por mais de cinco anos com agrotóxicos aumenta em 2,19 vezes as chances de desenvolver câncer hematológico $(\mathrm{OR}=2,19$; IC95\% 1,19 - 4,06). Verificou-se também que quanto maior a renda familiar, menores são as chances de surgimento dessas neoplasias (OR = 0,26; IC95\% 0,11 - 0,65). Além disso, os pacientes que não tinham histórico familiar de câncer tiveram $96 \%$ menos probabilidade (OR =0,04; IC95\% 0,02 - 0,08) de desenvolver a doença. A exposição crônica a agrotóxicos, o histórico familiar de câncer e o nível socioeconômico estão associados a maiores chances de 
desenvolver neoplasias hematológicas. Os trabalhadores rurais expostos a essas substâncias por períodos superiores a cinco anos são mais vulneráveis.

Palavras-chave: Exposição ocupacional; Neoplasias hematológicas; Pesticidas; Toxicologia.

\section{Resumen}

El objetivo de este estudio fue analizar la asociación entre la exposición crónica a plaguicidas y el desarrollo de cánceres hematológicos en una región con intensa actividad agrícola. Este es un estudio de casos y controles basado en un hospital. Se investigaron los aspectos socioeconómicos, demográficos, ocupacionales y relacionados con la salud de los pacientes. La razón de posibilidades (OR) univariante de los casos se verificó mediante análisis de regresión logística. En el análisis multivariado, las variables relevantes en el modelo se mantuvieron $(\mathrm{p}=0,05)$. Predominó el sexo masculino en los grupos caso $(54,0 \%)$ y control $(53,0 \%)$. La edad media fue de 58,8 $\pm 14,5$ años en el grupo de casos y de 55,6 $\pm 12,9$ años en el grupo de control. Se encontró que el 38,7\% de los casos eran agricultores, y que el contacto durante más de cinco años con plaguicidas aumenta 2,19 veces las posibilidades de desarrollar cánceres hematológicos ( $\mathrm{OR}=2,19$; IC 95\% 1, 19 - 4,06). También se encontró que cuanto mayor es el ingreso familiar, menor es la probabilidad de que aparezcan estas neoplasias ( $\mathrm{OR}=0,26$; IC del 95\%: 0,11 - 0,65). Además, los pacientes que no tenían antecedentes familiares de cáncer tenían un $96 \%$ menos de probabilidades $(\mathrm{OR}=$ 0,04; IC del 95\%: 0,02 - 0,08) de desarrollar la enfermedad. La exposición crónica a plaguicidas, los antecedentes familiares de cáncer y el nivel socioeconómico se asocian con mayores posibilidades de desarrollar neoplasias hematológicas. Los trabajadores rurales expuestos a estas sustancias durante períodos de más de cinco años son más vulnerables.

Palabras clave: Exposición ocupacional; Neoplasias hematológicas; Plaguicidas; Toxicología.

\section{Introduction}

Cancer remains a disease with a high incidence and high mortality rates (Bray et al., 2018). The cause of cancer is multifactorial and involves internal and external factors. Internal factors such as heredity, hormonal action and individual immunological conditions have an influence on oncogenesis. However, $80 \%$ to $90 \%$ of cancer cases are associated with external causes, and it is important to monitor the factors present in the environment (INCA, 2021).

In addition to ionizing radiation, infections and lifestyle, environmental and occupational exposures to chemical substances with carcinogenic potential, such as pesticides, are being increasingly studied (Moura et al., 2020; Vucenik \& Stains, 2012). These products, widely used in agriculture and in the domestic environment, are considered human carcinogens, since they act as tumor initiators and / or promoters (International Agency for Research on Cancer, 2015).

Chronic intoxication by organophosphate, pyrethroid and organochlorine pesticides, has been identified as a factor associated with the occurrence of hematological cancers, such as leukemias, lymphomas and myelomas (Lopes \& Albuquerque, 2018; Zakerinia, Namdari \& Amirghofran, 2012). Diazinon, chlorpyrifos, phonophos and malathion are examples of active principles associated with the increase of these neoplasms (Hu et al., 2012; Moase \& Chan, 2012; Schinasi \& Leon, 2014; Weichenthal).

Hematologic cancers concern a heterogeneous group of malignancies that affect hematopoietic precursors in the bone marrow. The organs most involved in this process are blood, bone marrow, lymph nodes, spleen, and liver. In oncological hematology, the main cancers are leukemias, lymphomas and myelomas. These cancers cause immunosuppression, which generally results from a combination of factors that determine the disease itself, as well as antineoplastic treatment (Búrigo et al., 2007).

Since 2008, the Brazilian market has been ranked first in the world ranking of pesticide consumption (Carneiro et al., 2015), and studies have associated morbidity and mortality from cancer with the indiscriminate use of these substances in some regions (Curvo et al., 2013; Dutra et al., 2020). Establishing causal links between the use of pesticides and the occurrence of cancer is a complex process, due to the heterogeneity of the compounds used in agriculture (Dutra \& Ferreira, 2019), the difficulties in determining their concentrations in organisms and performing biomonitoring. 
However, developing epidemiological studies that relate individual exposures to pesticides with the occurrence of cancer remains essential for public health. In this context, the aim of this study was to analyze the association between chronic exposure to pesticides and the development of hematological cancers in a region with intense agricultural activity.

\section{Methodology}

\subsection{Study design and location}

This is an observational, case-control, hospital-based study (IPTSP, 2017). The study was conducted in the municipality of Chapecó, located in the western region of Santa Catarina state, Brazil. The western region covers about 118 municipalities in the state, which together have an estimated population of approximately 1.2 million inhabitants (IBGE, 2010). The region's economy has agricultural activities as one of the main ones, with agriculture having a prominent position (EPAGRI/CEPA, 2019).

\subsection{Definition of the sample and study groups}

360 patients were included in the present study, 120 cases and 240 controls. The sample was calculated considering a proportion of exposed among the cases of $35.6 \%$, and among the controls of $23.4 \%$, with an odds ratio estimated at 1.8 . The level of significance adopted was $5 \%$, the test power $80 \%$, and the ratio of two controls for each case (2:1).

The case group consisted of patients admitted to a referral hospital for haemato-oncological treatment in western Santa Catarina. Patients of both sexes aged over 18 years, with hematological cancer were selected for this group. To make up the control group, twice as many patients, matched for age and sex, over 18 years old, were admitted to the same hospital for different treatments, except for cancer. Patients with a clinical history of other cancers were excluded from the case and control groups, as well as those who did not accept to participate in the study.

\subsection{Data collection}

After signing the Free and Informed Consent Form, a questionnaire was applied, in the form of an interview, to patients in both groups, containing variables related to socioeconomic, demographic, occupational, toxicological, and healthrelated aspects. The occupation of the participants was classified according to the Brazilian Classification of Occupations (CBO) of the Ministry of Labor and Employment (MTE), which considers groups from the level of competence and similarity in the activities carried out (MTE, 2010).

Figure 1. Brazilian Classification of Occupations of the Ministry of Labor and Employment.

\begin{tabular}{|c|c|}
\hline GG0 & Armed Forces, police, and military firefighters \\
\hline GG1 & $\begin{array}{c}\text { Senior members of the government, directors of public interest and press organizations and } \\
\text { managers }\end{array}$ \\
\hline GG2 & Professionals in science and the arts \\
\hline GG3 & Mid-level technician \\
\hline GG4 & Administrative service workers \\
\hline GG5 & Service workers, salespeople in stores and markets \\
\hline GG6 & Agricultural, forestry, hunting and fishing workers \\
\hline GG7 & Workers in the production of industrial goods and services* \\
\hline GG8 & Workers in the production of industrial goods and services** \\
\hline GG9 & Maintenance and repair workers \\
\hline
\end{tabular}

*GG 7 production system workers who tend to be discreet and who deal more with the shape of the product than with its physical-chemical content. ** GG8 workers in production systems that are or tend to be continuous (chemical, steel, among others). Source: MTE (2010). Source: Authors. 
To diagnostic confirmation, the analysis of the medical records of each patient was carried out concurrently with the interview by the researchers involved. The data collected through medical records referred to information such as: sex, age, skin color, education, socioeconomic level, place of residence, work activity, lifestyle, type of cancer (primary) and presence of metastasis.

\subsection{Ethical aspects}

Ethical aspects, aiming to preserve the dignity, rights, safety, and well-being of the research subject were strictly observed, and the study was approved by the Research Ethics Committee involving Human Beings of the Community University of the Region of Chapecó (Unochapecó), under number of opinion 2.942.429.

\subsection{Statistical analysis}

Descriptive statistics mean and standard deviation and frequency distribution (\%) were used. The variables were organized to consider the need for at least 10 cases in each group. Only variables that met this requirement were included in the regression analyzes. The age group variable was subcategorized in thirds. After the descriptive analysis, the data were analyzed to check the univariate odds ratio (OR) of cases with each independent variable, individually, using univariate logistic regression analysis.

The first multivariate model considered the predictor variables 'contact with pesticides' and 'time of contact with pesticides', and the confounding variable 'history of cancer in the family'. This model explained $31.5 \%$ of the total variation of the dependent variable (R2 of Cox and Snell). Then, there was a correlation between both predictor variables (Spearman's correlation coefficient $=-0.492 ; \mathrm{p}<0.001)$ and the variable 'contact with pesticides', which had the lowest Wald coefficient of the two, was excluded.

Subsequently, the multivariate model was subjected to sensitivity analysis, individually removing and reinserting each independent variable and observing the coefficients and 95\% confidence intervals (95\% CI), compared with the first adjusted model. Relevant variables were maintained in the model $(\alpha=0.05)$. The final model presented a Cox and Snell R2 of 0.333 . The results were presented as odds ratio (OR) and its $95 \%$ confidence interval (95\% CI). The analysis was conducted using the Statistical Package for Social Sciences (SPSS) 20.0 software.

\section{Results}

\subsection{Characterization of cases and controls}

The study sample consisted of 360 individuals, 120 cases and 240 controls. The socio-demographic and economic characteristics of the case and control groups are shown in Table 1. In both groups, there was a predominance of males, white skin color, primary education level and married marital status. The mean age of the sample was $50.2 \pm 16.2$ years, with $58.8 \pm$ 14.5 years in the case group and $55.6 \pm 12.9$ years in the control group. In the case group, patients aged over 61 years and with a minimum wage prevailed. In the control group, there was predominance of individuals aged 44 years or less, and with an income corresponding to two or three minimum wages. 
Table 1. Sociodemographic and economic variables of patients seen at a referral hospital for haemato-oncological treatment in western Santa Catarina, Brazil, 2020.

\begin{tabular}{|c|c|c|c|c|}
\hline \multirow[b]{2}{*}{ Variables } & \multicolumn{2}{|c|}{ Case Group } & \multicolumn{2}{|c|}{ Control Group } \\
\hline & $\mathrm{N}$ & $\%$ & $\mathrm{~N}$ & $\%$ \\
\hline \multicolumn{5}{|l|}{ Gender } \\
\hline Male & 68 & 54.0 & 128 & 53.0 \\
\hline Female & 52 & 46.0 & 112 & 47.0 \\
\hline \multicolumn{5}{|l|}{ Age (age range) } \\
\hline$\leq 44$ years & 30 & 25.0 & 104 & 43.3 \\
\hline 45 to 60 years & 40 & 33.3 & 74 & 30.8 \\
\hline$>61$ years & 50 & 41.7 & 62 & 25.9 \\
\hline \multicolumn{5}{|l|}{ Skin color } \\
\hline White & 96 & 80.0 & 187 & 77.9 \\
\hline Black & 5 & 4.2 & 2 & 0.8 \\
\hline Brown & 16 & 13.3 & 48 & 20.0 \\
\hline Yellow & 3 & 2.5 & 2 & 0.8 \\
\hline Indigenous & 0 & 0.0 & 1 & 0.4 \\
\hline \multicolumn{5}{|l|}{ Marital status } \\
\hline Single & 16 & 13.3 & 63 & 26.2 \\
\hline Married & 84 & 70.0 & 153 & 63.8 \\
\hline Divorced & 7 & 5.9 & 14 & 5.8 \\
\hline Widowed & 13 & 10.8 & 10 & 4.2 \\
\hline \multicolumn{5}{|l|}{ Education level } \\
\hline Illiterate & 5 & 4.1 & 6 & 2.5 \\
\hline Primary & 68 & 56.7 & 93 & 38,8 \\
\hline Lower and upper secondary & 36 & 30.0 & 86 & 35.8 \\
\hline Post-secondary & 11 & 9.2 & 55 & 22.9 \\
\hline \multicolumn{5}{|l|}{ Family income } \\
\hline 1 minimum wage & 58 & 48.3 & 67 & 27.9 \\
\hline 2 or 3 minimum wages & 49 & 40.8 & 121 & 50.4 \\
\hline Above 3 minimum wages & 13 & 10.9 & 52 & 21.7 \\
\hline \multicolumn{5}{|l|}{ Currently working } \\
\hline Yes & 44 & 36.7 & 172 & 71.7 \\
\hline No & 76 & 63.3 & 68 & 28.3 \\
\hline \multicolumn{5}{|l|}{ Current address } \\
\hline Urban & 80 & 66.7 & 181 & 75.4 \\
\hline Rural & 40 & 33.3 & 59 & 24.6 \\
\hline \multicolumn{5}{|l|}{ Previous address } \\
\hline Urban & 44 & 36.7 & 114 & 47.5 \\
\hline Rural & 76 & 63.3 & 126 & 52.5 \\
\hline
\end{tabular}

Source: Authors.

Regarding professional activity, in contrast to $71.1 \%$ of controls who reported working, $63.3 \%$ of cases reported that they did not have a professional occupation. Although most cases and controls resided in the urban area at the time of the interview, it is important to highlight the prevalence of the rural area as the previous address for both studied groups (Table 1).

\subsection{Life habits, occupation, and workload}

When asked about life habits, most cases declared that they were not smokers. Only three patients in the case group $(2.5 \%)$ and thirteen patients in the control group (5.4\%) reported smoking. As for occupation, it was found that $38.7 \%$ of cases belonged to the large group 6 of the Brazilian Classification of Occupations, which are characterized as agricultural, forestry, 
hunting and fishing workers.

In the control group, $24.7 \%$ of the participants were workers in the large group 7, characterized as workers in the production of industrial goods and services, who work more with the shape of the product than with its physical-chemical content.

Regarding the weekly workload, the interviewees in the case group reported working more than 44 hours a week, while those in the control group worked 40 to 44 hours a week. It is noteworthy that rural workers also had a workload of more than 44 hours.

\subsection{Exposure to pesticides and cancer}

It was found that $70.8 \%$ of cases and $81.3 \%$ of controls had no current contact with pesticides. However, when evaluating the participants' exposure time to these compounds, it was observed that $9.2 \%$ of cases reported exposure for a period of one to five years and $55.0 \%$ for six or more years. In the control group, $55.8 \%$ of patients did not report exposure to pesticides, as shown in Table 2.

Table 2. Current contact with pesticides and intoxication in patients seen at a referral hospital for haemato-oncological treatment in western Santa Catarina, Brazil, 2020.

\begin{tabular}{lllll}
\hline \multicolumn{2}{c}{ Case group* } & \multicolumn{2}{c}{ Control group** } \\
Variables & $\mathrm{N}$ & $\%$ & $\mathrm{~N}$ & $\%$ \\
\hline Current contact with pesticides & & & & \\
Yes & 35 & 29.2 & 45 & 18.7 \\
No & 85 & 70.8 & 195 & 81.3 \\
Contact length & & & & \\
None & 43 & 35.8 & 134 & 55.8 \\
1 up to 5 years & 11 & 9.2 & 26 & 10.8 \\
6 or more years & 66 & 55.0 & 80 & 33.4 \\
Intoxication symptoms & & & & \\
Yes & 15 & 12.5 & 20 & 8.3 \\
No & 105 & 87.5 & 220 & 91.7 \\
\hline
\end{tabular}

Source: Authors.

Among patients with occupational exposure to pesticides, $63.6 \%$ of cases and $61.3 \%$ of controls reported not using personal protective equipment. Regarding poisoning, $12.5 \%$ of cases and $8.3 \%$ of controls reported having suffered poisoning from these substances. Of these, 11 cases reported only one episode of intoxication, while four patients had two or more episodes. Intoxications occurred during work activities and only one event was accidental.

When questioned about the family history of neoplasms, $60.0 \%$ of the cases stated that they had cancer cases in the family, with $47.2 \%$ of these neoplasms in first-degree relatives (parents and children), followed by $43.0 \%$ in second degree (grandparents, grandchildren and siblings). In the control group, it was observed that only 15 individuals in this group (6.3\%) reported cases of neoplasms in the family.

Among the hematological cancers diagnosed in the cases, there was a predominance of non-Hodgkin's lymphoma, followed by Chronic Myeloid Leukemia and Multiple Myeloma, as shown in Table 3. 
Table 3. Types of hematological cancers diagnosed in patients seen at a reference hospital for haemato-oncological treatment in western Santa Catarina, Brazil, 2020.

\begin{tabular}{lcc}
\hline Diagnosis & N & \% \\
\hline Acute Myeloid Leukemia & 12 & 10.0 \\
Chronic Myeloid Leukemia & 26 & 21.7 \\
Acute Lymphoid Leukemia & 4 & 3.3 \\
Chronic Lymphoid Leukemia & 13 & 10.8 \\
Hodgkin's Lymphoma & 14 & 11.7 \\
Non-Hodgkin's Lymphoma & 33 & 27.5 \\
Multiple Myeloma & 18 & 15.0 \\
\hline
\end{tabular}

Source: Authors.

\subsection{Variables analyzed between the case and control groups and their respective odds ratios $(\mathrm{OR})$}

In the univariate logistic regression analysis, statistically significant differences were observed for most of the variables analyzed between the case and control groups, as shown in Table 4.

Table 4. Univariate regression analysis of the main variables with the respective odds ratios (OR), confidence intervals (95\% CI) and p values of patients seen at a reference hospital for haemato-oncological treatment in western Santa Catarina, Brazil, 2020 .

\begin{tabular}{|c|c|c|c|c|c|c|}
\hline \multirow[t]{2}{*}{ Variables } & \multicolumn{2}{|c|}{ Cases } & \multicolumn{2}{|c|}{ Control } & \multirow[t]{2}{*}{ OR (IC 95\%) } & \multirow[t]{2}{*}{$\mathbf{P}$} \\
\hline & $\mathbf{N}$ & $\%$ & $\mathbf{N}$ & $\%$ & & \\
\hline Gender & & & & & & 0.55 \\
\hline Male & 68 & 34.7 & 128 & 65.3 & 1 & \\
\hline Female & 52 & 31.7 & 112 & 68.3 & $0.87(0.56-1.36)$ & \\
\hline \multicolumn{7}{|c|}{ Age $($ Average $=50,2 ; \mathrm{DP}=16,2)$} \\
\hline$\leq 44$ & 30 & 22.4 & 104 & 77.6 & 1 & \\
\hline $45-60$ & 40 & 35.1 & 74 & 64.9 & $1.87(1.07-3.28)$ & $0.03 *$ \\
\hline $61+$ & 50 & 44.6 & 62 & 55.4 & $2.79(1.61-4.85)$ & $<0.001 *$ \\
\hline \multicolumn{7}{|l|}{ Education level } \\
\hline Primary & 73 & 42.4 & 99 & 57.6 & 1 & \\
\hline Lower and upper secondary & 36 & 29.5 & 86 & 70.5 & $0.57(0.35-0.93)$ & $0.02 *$ \\
\hline Post-secondary & 11 & 16.7 & 55 & 83.3 & $0.27(0.13-0.55)$ & $<0.001 *$ \\
\hline \multicolumn{7}{|l|}{ Family income } \\
\hline 1 Minimum wage & 58 & 46.4 & 67 & 53.6 & 1 & \\
\hline 2-3 Minimum wages & 49 & 28.8 & 121 & 71.2 & $0.47(0.28-0.76)$ & $0.002 *$ \\
\hline +3 Minimum wages & 13 & 20.0 & 52 & 80.0 & $0.29(0.14-0.58)$ & $0.001 *$ \\
\hline Current place of residence & & & & & & 0.08 \\
\hline Urban & 80 & 30.7 & 181 & 69.3 & 1 & \\
\hline Rural & 40 & 40.4 & 59 & 59.6 & $1.53(0.95-2.48)$ & \\
\hline Previous place of residence & & & & & & 0.052 \\
\hline Urban & 44 & 27.8 & 114 & 72.2 & 1 & \\
\hline Rural & 76 & 37.6 & 126 & 62.4 & $1.56(0.99-2.45)$ & \\
\hline Cancer cases in the family & & & & & & $<0.001 *$ \\
\hline Yes & 72 & 82.8 & 15 & 17.2 & 1 & \\
\hline No & 48 & 17.6 & 225 & 82.4 & $0.04(0.02-0.08)$ & \\
\hline Current occupational risk & & & & & & $0.001 *$ \\
\hline Yes & 47 & 47.0 & 53 & 53.0 & 1 & \\
\hline No & 73 & 28.1 & 187 & 79.9 & $0.44(0.27-0.71)$ & \\
\hline Previous occupational risk & & & & & & $<0.001 *$ \\
\hline Yes & 64 & 45.1 & 78 & 54.9 & 1 & \\
\hline No & 56 & 25.7 & 162 & 74.3 & $0.42(0.27-0.66)$ & \\
\hline Workload & & & & & & $<0.001 *$ \\
\hline$\leq 44$ Hours per week & 41 & 22.2 & 144 & 77.8 & 1 & \\
\hline Above 44 hours per week & 78 & 44.8 & 96 & 55.2 & $2.85(1.81-4.51)$ & \\
\hline Current pesticides contact & & & & & & $0.03 *$ \\
\hline
\end{tabular}




\begin{tabular}{|c|c|c|c|c|c|c|}
\hline \multirow[t]{2}{*}{ Variables } & \multicolumn{2}{|c|}{ Cases } & \multicolumn{2}{|c|}{ Control } & \multirow[t]{2}{*}{ OR (IC 95\%) } & \multirow[t]{2}{*}{$\mathbf{P}$} \\
\hline & $\mathbf{N}$ & $\%$ & $\mathbf{N}$ & $\%$ & & \\
\hline Yes & 35 & 43.8 & 45 & 56.3 & 1 & \\
\hline No & 85 & 30.4 & 195 & 69.6 & $0.56(0.34-0.93)$ & \\
\hline \multicolumn{7}{|l|}{ Pesticides contact length } \\
\hline None & 43 & 24.3 & 134 & 75.7 & 1 & \\
\hline Between 1 and 5 years & 11 & 29.7 & 26 & 70.3 & $1.32(0.60-2.88)$ & 0.49 \\
\hline Above 5 years & 66 & 45.2 & 80 & 54.8 & $2.57(1.60-4.13)$ & $<0.001 *$ \\
\hline \multicolumn{7}{|l|}{ Use of EPI $(n=360)$} \\
\hline No pesticide contact & 45 & 24.7 & 137 & 75.3 & 1 & \\
\hline $\begin{array}{l}\text { Contact with pesticide and } \\
\text { PPE use }\end{array}$ & 18 & 31.6 & 39 & 68.4 & $1.41(0.73-2.69)$ & 0.31 \\
\hline $\begin{array}{l}\text { Contact with pesticide and } \\
\text { no PPE use }\end{array}$ & 57 & 47.1 & 64 & 52.9 & $2.71(1.66-4.43)$ & $<0.001 *$ \\
\hline Previous intoxication & & & & & & 0.25 \\
\hline Yes & 14 & 42.4 & 19 & 57.6 & 1 & \\
\hline No & 106 & 32.4 & 221 & 67.6 & $0.65(0.32-1.35)$ & \\
\hline
\end{tabular}

Source: Authors.

3.5 Time of contact with pesticides, family history of cancer and family income: significant association with the development of hematological cancers

For the multivariate analysis, three variables relevant to the model were maintained: time of contact with pesticides, cancer in the family and family income. The results showed that all the variables analyzed showed a significant association with the development of hematological cancers, as shown in Table 5.

Table 5. Final model of the multivariate analysis of the association between the study covariates and development of hematological cancers of patients seen at a reference hospital for haemato-oncological treatment in western Santa Catarina, Brazil, 2020.

\begin{tabular}{|c|c|c|c|c|c|}
\hline Variables & $\begin{array}{l}\text { Gross OR } \\
\text { (IC 95\%) }\end{array}$ & $\mathbf{p}$ & $\mathbf{R}^{2}$ & $\begin{array}{c}\text { Adjusted OR } \\
\text { (IC 95\%) } \\
\mathbf{3 3 , 3 \%}\end{array}$ & $\mathbf{P}$ \\
\hline Family income & & $<0.001 *$ & 0.05 & & $<0.001 *$ \\
\hline Minimum wage & 1 & & & 1 & \\
\hline 2-3 Minimum wages & $0.47(0.29-0.76)$ & & & $0.50(0.27-0.93)$ & \\
\hline +3 Minimum wages & $0.29(0.14-0.58)$ & & & $0.26(0.11-0.65)$ & \\
\hline $\begin{array}{l}\text { Cancer cases in the } \\
\text { family }\end{array}$ & & $<0.001 *$ & 0.30 & & $<0.001 *$ \\
\hline Yes & 1 & & & 1 & \\
\hline No & $0.04(0.02-0.08)$ & & & $0.04(0.02-0.08)$ & \\
\hline Pesticide contact length & & $<0.001 *$ & 0.04 & & $<0.001 *$ \\
\hline No contact & 1 & & & 1 & \\
\hline 1 to 5 years contact & $1.32(0.60-2.89)$ & & & $1.56(0.60-4.05)$ & \\
\hline Above 5 years & $2.57(1.60-4.13)$ & & & $2.19(1.19-4.06)$ & \\
\hline
\end{tabular}

Source: Authors. 


\section{Discussion}

Considering the literature to which we had access, this is the first case-control study carried out in southern Brazil to assess risk factors for the development of hematological cancers. The results showed that prolonged exposure to pesticides, family history of cancer and socioeconomic condition increase the chances for the development of this type of cancer.

In this study, an adjusted odds ratio of 2.19, 95\% CI (1.19 - 4.06) was found for participants who had been in contact with pesticides for five years or more. Chronic exposure to these compounds is considered one of the factors associated with the development of cancer, due to the genotoxic, mutagenic, and carcinogenic potential for cells (IARC, 2015). Therefore, this result corroborates the positive association between prolonged exposure to pesticides and the increased chances of occurrence of hematological cancers, found in national and international literature in the last decade (Moura, 2019; Navaranjan et al., 2013).

According to a survey conducted in the studied region, it was shown that organophosphate and carbamate pesticides are widely used and affect the health of rural workers who suffer intoxications, demonstrated by decreased activity of the erythrocyte acetylcholinesterase enzyme (Lorenzatto et al., 2020). Prolonged exposure to compounds belonging to these chemical groups can also increase the risk of hematological cancers (Moura, 2020).

As in the studied region, intoxication of rural workers by pesticides is common in several regions of Brazil Lara et al. (2019), Lorenzatto et al. (2020), and Moura (2020) due to the intensive use of these products in agriculture, which corresponds to approximately $20 \%$ of total use worldwide. Among the active ingredients used, we can mention: glyphosate, 2,4-D, atrazine, carbendazim, cypermethrin, metamidophos and acephate (IBAMA, 2017), all classified as endocrine disruptors (Mnif et al., 2011). The risks associated with cancer have also been evidenced, mainly by the use of glyphosate and 2,4-D, the most consumed pesticides in the country (IARC, 2015).

Among the most prevalent hematological cancers in this study, non-Hodgkin's lymphoma stands out, whose development may also be at greater risk in individuals who use pesticides (Balasubramaniam et al., 2013; Karunanayake, Dosman \& Pahwa, 2013; Rudant et al., 2007; Vajdic et al., 2007). In addition to lymphomas, multiple myeloma, which obtained a prevalence of $15 \%$ in this study, can be associated with occupational exposure to pesticides Merhi et al. (2007) and Perrotta et al. (2013), the longer the exposure periods, the greater the chances of developing multiple myeloma (Kachuri et al., 2013; Landgren et al., 2009; Lope et al. 2008).

The risks associated with contact with pesticides are difficult to clarify due to the involvement of several factors, such as the period and level of exposure, the age group of individuals, the physical properties of the substances involved (volatility, toxicity and persistence), in addition to the environmental characteristics of contaminated areas (Alavanja et al., 2003; Kim, Kabir \& Jahan, 2017). Another important factor is that the chronic effects become apparent after years of exposure and, sometimes, it is not possible to relate the exposure by these substances to the diagnosis of cancer (Londres, 2011).

As exposure to pesticides can be associated with greater chances of developing hematological neoplasms, they are also related to higher mortality rates among rural workers (Coggon et al., 2015). In this case, the work environment becomes conducive to prolonged exposure to carcinogenic substances, which increases the risk of cancer (INCA, 2015). In this study, there was a predominance of agricultural workers in the group (38.7\%), which includes farmers, considered the most vulnerable to exposure to pesticides. The farmers have been exposed over the years to different types of pesticides, preparing and applying them. In addition, it can be exposed in the residence itself, through storage, inappropriate disposal and handling of the clothes used during application (Preza \& Augusto, 2012; Santos et al., 2017).

As pointed out in this study, out of patients occupationally exposed to pesticides, more than $60 \%$ did not use protective equipment, which increases exposure. In Brazilian agriculture, the inappropriate use of personal protective 
equipment is a serious problem, and it is common to find rural workers who do not use them during the handling and application of agricultural chemicals, even knowing the risks related to the use of these substances for their health (Moura, 2019; Santos, Borges-Paluch et al., 2017; Viero et al., 2016).

It was not possible to determine the classes of pesticides and the types of chemical substances to which the patients were exposed, since at the time of the interview, the patients were unable to report the names of the active ingredients of the pesticides or their trademarks. This fact calls attention to the lack of knowledge of rural workers about the products they use in their activities.

It is important to note that pesticide poisoning can also occur indirectly, since the environment, springs and water in regions close to agricultural areas may be contaminated with residues of these substances, as well as food (Novais, Queiroz \& Seabra Júnior, 2021). In this case, the problem of contamination can extend to urban areas, constituting a risk for the population. The ingestion of contaminated water and food can predispose to the emergence of endocrine diseases and cancer due to the accumulation of pesticides in the body (Palma \& Lourencetti, 2011).

Another relevant data found in this study was the significant association between the family cancer history and the risk of hematological cancers. In fact, family histories of cancer, along with age, are important risk factors for most hematological cancers (INCA, 2021). Genetic changes that promote mutations in DNA predispose to the onset of the disease. In addition, with the inherited change, there is a 50\% chance that the mutation will be passed on to each of the descendants. This increased risk in people with a hereditary mutation is described as genetic susceptibility (Instituto Oncoguia, 2015).

In this study, it was also found that the lower the family income, the greater the chances of developing hematological cancers. It is known that when financial resources are available, there is an improvement in the quality of life. Lifestyle, education level, socioeconomic conditions and other factors directly interfere in the daily routine for a healthy life. The adoption of a healthy life is an objective of cancer prevention, as it comprises actions that reduce the risks of having the disease. These actions include healthy food, physical activity, maintaining adequate weight, access to health services, use of preventive measures and diagnosis of diseases, in addition to early detection of precancerous conditions (Freire et al., 2019).

Of the patients in the case group, $48.3 \%$ had a family income of one minimum wage. Lower income may be associated with more stressful working conditions and greater exposure to occupational risk factors. Low-income individuals have less health concerns and greater difficulty in accessing health services and information. Consequently, it results in a higher incidence of disease and, in turn, a greater need for health care (Santos, Tavares \& Barabosa, 2010).

In addition to improving the quality of life, the relationship with health is established due to the higher educational level, which provides individuals with greater capacity to participate in prevention programs, self-care and to cope with health problems (Liu \& Hummer, 2008). On the contrary, the low level of education is associated with unhealthy lifestyle habits, morbidity and early mortality (IBGE, 2018).

Although the possibility of memory bias should be considered as a limitation of the study, due to the responses of patients at the time of applying the questionnaires, the results of this research are similar to the findings in other studies. Therefore, they corroborate the hypothesis of increased chances of developing hematological cancers in workers exposed to pesticides (Moura, 2019; Zakerinia, Namdari \& Amirghofran, 2012).

Vulnerabilities related to work processes that can increase exposure to these compounds, such as inadequate use of PPE, lack of knowledge about handled pesticides and prolonged exposure time were also verified, as described by Moura (2019).

\section{Conclusion}

Our results demonstrate that chronic exposure to pesticides, family history of cancer and socioeconomic condition are 
associated with greater chances of developing hematological neoplasms. Rural workers exposed to these substances for periods of more than five years are more vulnerable. These data are relevant to public health and constitute yet another warning related to the negative impacts of pesticides on human health.

New studies involving this population need to be carried out, and it is important to investigate the active ingredients of pesticides most used in cases of chronic exposure. In addition, studies involving the analysis of biomarkers would also bring interesting results, making it possible to prove intoxication by these compounds.

\section{References}

Alavanja, M. C. R., Samanic, C., Dosemeci, M., Lubin, J., Tarone, R., Lynch, C. F., Knott, C., Thomas, K., Hoppin, J. A., Barker, J., Coble, J., Sandler, D. P. \& Blair, A. (2003). Use of agricultural pesticides and prostate cancer risk in the agricultural health study cohort. American. Journal of Epidemiology, 157(9), 800-814. https://academic.oup.com/aje/article/157/9/800/97345?login=true

Balasubramaniam, G., Saoba, S., Sarade, M., \& Pinjare, S. (2013). Case-control study of risk factors for Non-Hodgkin lymphoma in Mumbai, India. Asian Pacific Journal of Cancer Prevention, 14(2), 775-780. https://www.koreascience.or.kr/article/JAKO201321251180093.page

Bray, F., Ferlay, J., Soerjomataram, I., Siegel, R. L., Torre, L. A., \& Jemal, A. (2018). Global cancer statistics 2018: GLOBOCAN estimates of incidence and mortality worldwide for 36 cancers in 185 countries. CA: A Cancer Journal for Clinicians, 68(6), 394-424. https://acsjournals.onlinelibrary.wiley.com/doi/full/10.3322/caac.21492

Búrigo, T., Fagundes, R. L., Trindade, E. B., Vasconcelos, H. C., Massaut, I. H., \& Rotolo, M. A. S. (2007). Ação do prebiótico sobre as proteínas de fase aguda de pacientes com neoplasia hematológica. Revista Brasileira de Hematologia e Hemoterapia, 29, 130-135. https://www.scielo.br/j/rbhh/a/NZ5FY36yqc7PxSRV8fJpXmc/abstract/?lang=pt

Carneiro, F. F. (2015). Dossiê ABRASCO: um alerta sobre os impactos dos agrotóxicos na saúde. EPSJV/Expressão Popular. https://www.arca.fiocruz.br/bitstream/icict/26221/2/Livro\%20EPSJV\%20013036.pdf

Coggon, D., Ntani, G., Harris, E. C., Jayakody, N., \& Palmer, K. T. (2015). Soft tissue sarcoma, non-Hodgkin's lymphoma and chronic lymphocytic leukaemia in workers exposed to phenoxy herbicides: extended follow-up of a UK cohort. Occupational and Environmental Medicine, 72(6), 435-441. https://oem.bmj.com/content/72/6/435.short

Costa, V. I. do B., Mello, M. S. \&“Friedrich, C. K. (2017). Exposição ambiental e ocupacional a agrotóxicos e o linfoma não Hodgkin. Saúde Em Debate, 41 (112), 49-62. https://www.scielosp.org/article/sdeb/2017.v41n112/49-62/

Curvo, H. R. M., Pignati, W. A., \& Pignatti, M. G. (2013). Morbimortalidade por câncer infantojuvenil associada ao uso agrícola de agrotóxicos no Estado de Mato Grosso, Brasil. Cadernos Saúde Coletiva, 21(1), 10-17. https://www.scielo.br/j/cadsc/a/QBWbWbZL3KxBPLXfRKgtwyd/?lang=pt

Dalamaga, M., Christodoulatos, G. S. \& Mantzoros, C. S. (2018). The role of extracellular and intracellular Nicotinamide phosphoribosyl-transferase in cancer: Diagnostic and therapeutic perspectives and $72-87$. https://www.sciencedirect.com/science/article/abs/pii/S0026049518300052

Dutra, L. S. \& Ferreira, A.P. (2019). Tendência de malformações congênitas e utilização de agrotóxicos em commodities: um estudo ecológico. Saúde em Debate, 43 (121), 390-405. https://www.scielo.br/j/sdeb/a/5PwnsCcxdgtXTzHQtDrbSMG/abstract/?lang=pt

Dutra, L. S., Ferreira, A. P., Horta, M. A. P., \& Palhares, P. R. (2020). Uso de agrotóxicos e mortalidade por câncer em regiões de monoculturas. Saúde em Debate, 44, 1018-1035. https://www.scielo.br/j/sdeb/a/FfpPSnKCkxrdqPd8ptnfWsJ/?format=html\&lang=pt

Empresa de Pesquisa Agropecuária e Extensão Rural de Santa Catarina - EPAGRI/CEPA. (2019). Síntese Anual da Agricultura de Santa Catarina 2017 2018. https://publicacoes.epagri.sc.gov.br/SAA/article/view/517

Freire, M. E. M., Costa, S. F. G., de Lima, da R. A. G. \& Sawada, N. O. (2018). Qualidade de vida relacionada à saúde de pacientes com câncer em cuidados paliativos. Texto \& Contextexto Enfermagem, 27(2), e5420016. https://www.scielo.br/j/tce/a/br6jYdcz5C5r8kVkctrpfPG/?format=pdf\&lang=pt

Hu, L., Luo, D., Zhou, T., Tao, Y., Feng, J., \& Mei, S. (2017). The association between non-Hodgkin lymphoma and organophosphate pesticides exposure: A meta-analysis. Environmental Pollution, 231, 319-328. https://www.sciencedirect.com/science/article/abs/pii/S0269749117307170

Instituto Brasileiro de Geografia e Estatistica - $\quad$ IBGE. (2010). Censo Demográfico. Santa Catarina. https://www.ibge.gov.br/estatisticas/sociais/populacao/9662-censo-demografico-2010.html?=\&t=resultados

Instituto Brasileiro de Geografia e Estatistica - IBGE. (2018). Coordenação de População e Indicadores Sociais. Síntese de Indicadores Sociais: uma análise das condições de vida da população brasileira. Rio de Janeiro: IBGE. https://biblioteca.ibge.gov.br/visualizacao/livros/liv101629.pdf

Instituto Brasileiro do Meio Ambiente e dos Recursos Naturais Renováveis - IBAMA. (2017.) Boletim Anual de Produção, Importação, Exportação e Vendas de Agrotóxicos no Brasil. http://www.ibama.gov.br/agrotoxicos/relatorios-de-comercializacao-de-agrotoxicos\#boletinsanuais

Instituto Nacional de Câncer - INCA. (2015). Posicionamento do Instituto Nacional de Câncer José Alencar Gomes da Silva Acerca dos Agrotóxicos. https://www.inca.gov.br/sites/ufu.sti.inca.local/files//media/document//posicionamento-do-inca-sobre-os-agrotoxicos-06-abr-15.pdf

Instituto Nacional de Câncer - INCA. (2021). Prevenção e fatores de risco. https://www.inca.gov.br/causas-e-prevencao/prevencao-e-fatores-de-risco 
Instituto Oncoguia. (2015). Câncer Hereditário. http://www.oncoguia.org.br/conteudo/cancer-hereditario/8323/73

International Agency for Research on Cancer - IARC. (2015). World Health Organization. Evaluation of five organophosphate insecticides and herbicides. IARC Monographs, 112. https://publications.iarc.fr/Book-And-Report-Series/Iarc-Monographs-On-The-Identification-Of-Carcinogenic-Hazards-ToHumans/Some-Organophosphate-Insecticides-And-Herbicides-2017

International Agency fro Research on Cancer - IARC. (2018). World Health Orbanization. DDT, lindane, and 2, 4-D. IARC Monographs, 113. https://www.ncbi.nlm.nih.gov/books/NBK507424/

Instituto de Patologia Tropical e Saúde Pública - IPTSP (2017). Universidade Federal de Goiás (UFG). Estudos de Caso-Controle. https://posstrictosensu.iptsp.ufg.br/up/59/o/Modulo3-Estudosdecaso-controle.pdf

Kachuri, L., Demers, P. A., Blair, A., Spinelli, J. J., Pahwa, M., McLaughlin, J. R., Pahwa, P., Dosman, J. A. \& Harris, S. A (2013). Multiple pesticide exposures and the risk of multiple myeloma in Canadian men. International Journal of Cancer, 133(8), 1846-1858. https://onlinelibrary.wiley.com/doi/full/10.1002/ijc.28191

Karunanayake, C. P., Dosman, J. A., \& Pahwa, P. (2013). Non-hodgkin's lymphoma and work in agriculture: Results of a two case-control studies in Saskatchewan, Canada. Indian Journal of Occupational and Environmental Medicine, 17(3), 114. https://www.ncbi.nlm.nih.gov/pmc/articles/PMC4035607/

Kim, K. H., Kabir, E., \& Jahan, S. A. (2017). Exposure to pesticides and the associated human health effects. Science of the Total Environment, 575, 525-535. https://www.sciencedirect.com/science/article/abs/pii/S004896971631926X

Landgren, O., Kyle, R. A., Hoppin, J. A., Beane Freeman, L. E., Cerhan, J. R., Katzmann, J. A., Rajkumar, S. V., Alavanja, M. C. R. (2009). Pesticide exposure and risk of monoclonal gammopathy of undetermined significance in the Agricultural Health Study. Blood, The Journal of the American Society of Hematology, 113(25), 6386-6391. https://ashpublications.org/blood/article/113/25/6386/25684/Pesticide-exposure-and-risk-of-monoclonal

Lara, S. S. de, Pignati, W. A., Pignatti, M. G., da Costa Leão, L. H., \& Machado, J. M. H. (2019). A agricultura do agronegócio e sua relação com a intoxicação aguda por agrotóxicos no Brasil. Hygeia - Revista Brasileira de Geografia Médica e da Saúde, 15(32), 1-19. http://www.seer.ufu.br/index.php/hygeia/article/view/46822

Liu, H., \& Hummer, R. A. (2008). Are educational differences in US self-rated health increasing?: An examination by gender and race. Social Science \& Medicine, 67(11), 1898-1906. https://www.sciencedirect.com/science/article/abs/pii/S0277953608004723

Londres, F. (2012). Agrotóxicos no Brasil: um guia para ação em defesa da vida. Rede Brasileira de Justiça Ambiental. https://br.boell.org/ptbr/2011/10/31/agrotoxicos-no-brasil-um-guia-para-acao-em-defesa-da-vida-0

Lope, V., Pérez-Gómez, B., Aragonés, N., López-Abente, G., Gustavsson, P., Plato, N., Zock, J. P. \& Pollán, M. (2008). Occupation, exposure to chemicals, sensitizing agents, and risk of multiple myeloma in Sweden. Cancer Epidemiology and Prevention Biomarkers, 17(11), 3123-3127. https://cebp.aacrjournals.org/content/17/11/3123.short

Lopes, C. V. A., \& Albuquerque, G. S. C. D. (2018). Agrotóxicos e seus impactos na saúde humana e ambiental: uma revisão sistemática. Saúde em Debate, 42 (117), 518-534. https://www.scielo.br/j/sdeb/a/bGBYRZvVVKMrV4yzqfwwKtP/abstract/?lang=pt

Lorenzatto, L. B., da Silva, M. I. G., Junior, W. A. R., Junior, S. A. R., De Sá, C. A., \& Corralo, V. (2020). Exposição de trabalhadores rurais a organofosforados e carbamatos. Brazilian Journal of Environmental http://www.rbciamb.com.br/index.php/Publicacoes_RBCIAMB/article/view/528

Luo, D., Zhou, T., Tao, Y., Feng, Y., Shen, X. \& Mei, S. (2016). Exposure to organochlorine pesticides and non-Hodgkin lymphoma: A meta-analysis of observational studies. Scientific Reports, 6(1), 1-11. https://www.nature.com/articles/srep25768

Merhi, M., Raynal, H., Cahuzac, E., Vinson, F., Cravedi, J. P., \& Gamet-Payrastre, L. (2007). Occupational exposure to pesticides and risk of hematopoietic cancers: meta-analysis of case-control studies. Cancer Causes \& Control, 18(10), 1209-1226. https://link.springer.com/article/10.1007/s10552-007-9061-1 Ministério do Trabalho e Emprego - MTE. (2010). Classificação Brasileira de Ocupações: CBO-2010. https://portalfat.mte.gov.br/wpcontent/uploads/2016/04/CBO2002_Liv3.pdf

Mnif, W., Hassine, A. I. H., Bouaziz, A., Bartegi, A., Thomas, O., \& Roig, B. (2011). Effect of endocrine disruptor pesticides: a review. International Journal of Environmental Research and Public Health, 8(6), 2265-2303. https://www.mdpi.com/1660-4601/8/6/2265

Mostafalou, S., \& Abdollahi, M. (2017). Pesticides: an update of human exposure and toxicity. Archives of Toxicology, 91(2), 549-599. https://link.springer.com/article/10.1007\%2Fs00204-016-1849-x

Moura, L. T. R. de. (2019). Fatores de risco associados à presença de neoplasias hematológicas no polo fruticultor Petrolina (PE)/Juazeiro (BA). (Tese). https://pesquisa.bvsalud.org/hansen/resource/pt/biblio-1099806?src=similardocs

Moura, L. T. R. D., Bedor, C. N. G., Lopez, R. V. M., Santana, V. S., Rocha, T. M. B. D. S. D., Wünsch Filho, V., \& Curado, M. P. (2020). Exposição ocupacional a agrotóxicos organofosforados e neoplasias hematológicas: uma revisão sistemática. Revista Brasileira de Epidemiologia, 23, e200022. https://www.scielosp.org/article/rbepid/2020.v23/e200022/pt/

Navaranjan, G., Hohenadel, K., Blair, A., Demers, P. A., Spinelli, J. J., Pahwa, P., McLaughlin, J. R., Dosman, J. A., Ritter, L. \& Harris, S. A. (2013). Exposures to multiple pesticides and the risk of Hodgkin lymphoma in Canadian men. Cancer Causes \& Control, 24(9), 1661-1673. https://link.springer.com/article/10.1007/s10552-013-0240-y

Neves, P. D. M., Mendonça, M. R., Bellini, M. I \& Pôssas, B. (2020). Intoxicação por agrotóxicos agrícolas no estado de Goiás, Brasil, de 2005-2015: análise dos registros nos sistemas oficiais de informação. Ciência \& Saúde Coletiva, 25, 2743-2754. https://www.scielosp.org/article/csc/2020.v25n7/2743-2754/ 
Novais, C. M., de Queiroz, T. M., \& Júnior, S. S. (2021). Panorama da contaminação ambiental por agrotóxicos no estado do mato grosso: risco para o abastecimento urbano. Research, Society and Development, 10(1), e23010111667-e23010111667.

Palma, D. C. de A., \& Lourencetti, C. (2011). Agrotóxicos em água e alimentos: risco a saúde humana. Revista Brasileira Multidisciplinar, 14(2), 7-21. https://www.revistarebram.com/index.php/revistauniara/article/view/108

Perrotta, C., Kleefeld, S., Staines, A., Tewari, P., De Roos, A. J., Baris, D., Birmann, B., Chiu, B., Cozen, W., Becker, N., Foretova, L., Maynadié, M., Nieters, A., De Sanjosé, S., Miligi, L. Seniori Costantini, A., Purdue, M., Spinelli, J. \& Cocco, P. (2013). Multiple myeloma and occupation: a pooled analysis by the International Multiple Myeloma Consortium. 300-305. https://www.sciencedirect.com/science/article/abs/pii/S187778211300012X

Perrotta, C., Staines, A., Codd, M., Kleefeld, S., Crowley, D., T’ Mannetje, A., Becker, N., Brennan, P., De Sanjosé, S., Foretova, L., Maynadié, M., Nieters, A., Boffetta, P. \& Cocco, P. (2012). Multiple Myeloma and lifetime occupation: results from the EPILYMPH study. Journal of Occupational Medicine and Toxicology, 7(1), 1-6. https://occup-med.biomedcentral.com/articles/10.1186/1745-6673-7-25

Preza, D. de L. C \& Augusto, L. G. da S. (2012). Vulnerabilidades de trabalhadores rurais frente ao uso de agrotóxicos na produção de hortaliças em região do Nordeste do Brasil. Revista Brasileira de Saúde Ocupacional, 37, 89-98. https://www.scielo.br/j/rbso/a/tBb4YhMVcDbX3PVHKKHHg7S/abstract/?lang=pt

Rudant, J., Menegaux, F., Leverger, G., Baruchel, A., Nelken, B., Bertrand, Y., Patte, C., Pacquement, H., Vérité, C., Robert, A., Michel, G., Margueritte, G., Gandemer, V., Hémon, D. \& Clavel, J. (2007). Household exposure to pesticides and risk of childhood hematopoietic malignancies: the ESCALE study (SFCE). Environmental Health Perspectives, 115(12), 1787-1793. https://ehp.niehs.nih.gov/doi/full/10.1289/ehp.10596

Santos, A. de O., Borges-Paluch, L. R., Cerqueira, T. P. dos S. \& Teles, A. L. B. (2017). Utilização de equipamentos de proteção individual e agrotóxicos por agricultores de município do recôncavo Baiano. Revista da Universidade Vale do Rio Verde, 15(1), 738-754. http://periodicos.unincor.br/index.php/revistaunincor/article/view/3309

Santos, S., Tavares, D. \& Barabosa, M. (2010). Fatores socioeconômicos, incapacidade funcional e número de doenças entre idosos. Revista Eletrônica de Enfermagem, 12(4), 692-7. https://www.revistas.ufg.br/index.php/fen/article/view/7628

Schinasi, L. \& Leon, M. E. (2014). Non-Hodgkin lymphoma and occupational exposure to agricultural pesticide chemical groups and active ingredients: a systematic review and meta-analysis. International Journal of Environmental Research and Public Health, 11(4), 4449-4527. https://www.mdpi.com/16604601/11/4/4449/htm

Vajdic, C. M., Fritschi, L., Grulich, A. E., Kaldor, J. M., Benke, G., Kricker, A, Hughes, A. M., Turner, J. J., Milliken, S., Goumas, C. \& Armstrong, B. K. (2007). Atopy, exposure to pesticides and risk of non-Hodgkin lymphoma. International Journal of Cancer, 120(10), 2271-2274. https://onlinelibrary.wiley.com/doi/full/10.1002/ijc.22602

Viero, C. M., Camponogara, S., Cezar-Vaz, M. R., Costa, V. Z. D., \& Beck, C. L. C. (2016). Risk society: the use of pesticides and implications for the health of rural workers. Escola Anna Nery, 20(1), 99-105.

Vucenik, I.., \& Stains, J. P. (2012). Obesity and cancer risk: evidence, mechanisms, and recommendations. Annals of the New York Academy of Sciences, 1271(1), 37. https://www.ncbi.nlm.nih.gov/pmc/articles/PMC3476838/

Weichenthal, S., Moase, C. \& Chan, P. (2010). A review of pesticide exposure and cancer incidence in the Agricultural Health Study cohort. Environmental Health Perspectives, 118(8), 1117-1125. https://ehp.niehs.nih.gov/doi/full/10.1289/ehp.0901731

Zakerinia, M., Namdari, M. \& Amirghofran, S. (2012). The relationship between exposure to pesticides and the occurrence of lymphoid neoplasm. Iranian Red Crescent Medical Journal, 14(6), 337. https://www.ncbi.nlm.nih.gov/pmc/articles/PMC3420024/ 